\title{
STUDI AWAL SEISMOTEKTONIK DI WILAYAH JAWA BARAT BERDASARKAN RELOKASI HIPOSENTER METODE DOUBLE DIFFERENCE
}

\author{
Tri Kusmita ${ }^{1}$, llham Pribadi ${ }^{2}$, Nasri MZ, Supriyanto Rohadi ${ }^{3}$ \\ ${ }^{1}$ Jurusan Fisika, Fakultas Teknik, Universitas Bangka Belitung, Kepulauan Bangka Belitung \\ ${ }^{2}$ Program Studi Teknik Geofisika, Fakultas Sains dan Teknologi, Universitas Jambi, Jambi, \\ ${ }^{3}$ Badan Meteorologi, Klimatologi dan Geofisika, Jakarta. \\ e-mail : trikusmita@gmail.com
}

\begin{abstract}
Abstrak. Jawa barat mempunyai aktivitas kegempaan yang sangat tinggi. Aktivitas kegempaan di wilayah Jawa Barat dikontrol oleh struktur geologi regional dan keberadaan sesar-sesar lokal. Aktivitas sesar-sesar lokal dan zona keberadaan zona subduksi dapat dipelajari dari sebaran hiposenter pada daerah tersebut. Sebaran hiposenter yang diperoleh dari katalog BMKG biasanya berasal dari quick count dengan mengabaikan beberapa parameter. Oleh karena itu, lokasi hiposenter tersebut harus direlokasi untuk menentukan hubungan hiposenter gempa dengan aktivitas tektonik daerah tersebut. Metode relokasi hiposenter yang digunakan adalah metode Double Difference. Metode ini digunakan untuk mengidentifikasi zona patahan berdasarkan distribusi gempa yang terjadi. Prinsip metode Double Difference adalah jarak persebaran hiposenter antara dua gempabumi sangat kecil dibandingkan dengan jarak antara stasiun gempabumi, maka raypath dan waveform kedua gempabumi dapat dianggap mendekati sama. Data yang digunakan dalam penelitian ini adalah data gempabumi yang terjadi pada periode Juli 2017-Juni 2018 di Jawa Barat. Hasil relokasi hiposenter menunjukkan bahwa kegempaan di Jawa Barat Sebagian besar berasosiasi dengan zona subduksi. Penunjaman yang terjadi relatif landai. Kedalaman aktivitas gempabumi pada zona subduksi tersebut sekitar 0-70 km. Aktifitas kegempaan pada Sesar-sesar lokal relatif sangat dangkal dan tersebar hampir di setiap segmen sesar lokal.

Kata Kunci: Relokasi; Double Difference; Jawa Barat; Seismotektonik
\end{abstract}

\begin{abstract}
West Java has a very high seismic activity. Seismic activity in West Java was controlled by regional geological structures and the presence of local faults. The activity of local faults and the subduction zone can be studied from the hypocenter distribution in the area. The distribution of hypocenter obtained from the BMKG catalog usually comes from a quick count by ignoring several parameters. Therefore, the location of the hypocenter must be relocated to determine the relationship of the hypocenter of the earthquake to the tectonic activities of the area. The hypocenter relocation method used in this study was the Double Difference method. This method was used to identify fault zones based on the distribution of earthquakes that occur. The principle of the Double Difference method was the distance of the hypocenter distribution between two earthquakes is very small compared to the distance between the earthquake station, so the raypath travel times and waveform of both earthquakes can be considered to be the same. The data used in this study was earthquake data that occurred in the period July 2017-June 2018 in West Java about 710 seismic events. Hypocenter relocation results show that seismicity in West Java is associated with subduction zones. The subduction that occurred was relatively gentle. The depth of earthquake activity in the subduction zone was around 0-70 km. Seismic activity in local faults relatively very shallow and it was spread in every local fault segment.
\end{abstract}

Keywords: Relocation; Double Difference; Wast Java; Seismotectoni

\section{PENDAHULUAN}

Struktur geologi yang berkembang di Jawa Barat pada dasarnya dipengaruhi oleh aktivitas tumbukan Lempeng Indo-Australia yang menunjam di bawah Lempeng Eurasia (Hamilton dkk., 1979). Akibat dari adanya aktivitas tumbukan lempeng ini menghasilkan elemen tektonik utama di Jawa Barat berupa palung, busur luar non vulkanik, cekungan depan busur, jalur magmatisma, cekungan belakang busur dan paparan sunda (Katili, 1975).

Struktur geologi regional lainnya dapat dilihat dipermukaan baik melalui pengamatan langsung di lapangan maupun dari citra indraja, misalnya Sesar Cimandiri, Sesar Baribius dan Sesar Lembang. Sesar Cimandiri mewakili pola Meratus sedangkan sesar Baribis dan sesar lembang mewakili pola Jawa. 
Pembentukan ketiga pola sesar tersebut juga diiukuti oleh aktifitas vulkanik sejalan dengan terus berlangsungnya aktivitas tumbukan lempeng (Haryanto, 2006). Perubahan posisi jalur gunungapi di Jawa Barat tentunya berkaitan dengan adanya perubahan jalur subduksi atau mungkin juga terjadi akibat adanya perubahan sudut zona tunjaman. Perubahan inilah yang mempengaruhi pula pembentukan struktur geologi regional di Jawa Barat khususnya.

Posisi jalur subduksi di Jawa barat berubahubah, namun arah jalur subduksinya relatif sama, yaitu relatif berarah Barat-Timur. Posisi tumbukan ini menghasilkan sistem tegasan (gaya) berarah utaraselatan. Satuan tektonik Jawa Barat yang kompleks (mélange) merupakan satuan tektonik tertua di Jawa Barat adalah jalur Subduksi yang berumur Pra-Eosen di Ciletuh (selatan Pelabuhan Ratu) Jawa Barat. Satuan tektonik lainnya adalah jalur magma tersier sepanjang jalur selatan Pulau Jawa (Hilmi dan Haryanto, 2008).

Akibat dari struktur geologi regional tersebut, daerah Jawa bagian Barat mempunyai intensitas kegempaan yang sangat tinggi (Gambar 1). Wilayah dalam kotak hitam pada gambar tersebutmerupakan daerah penelitian. Salah satu metode yang banyak digunakan dalam mengkaji tentang aktivitas kegempaan adalah dengan cara melakukan relokasi hiposenter.

Relokasi Hiposenter gempabumi dilakukan untuk mendapatkan hasil distribusi lokasi hiposenter gempa yang lebih akurat. Hal ini dikarenakan lokasi hiposenter hasil perhitungan cepat pada katalog BMKG masih mengabaikan beberapa parameter utama dan beberapa koreksi. Hal ini tidak memberikan dampak yang signifikan ketika informasi lokasi hiposenter yang diinginkan berskala besar. Akan tetapi dalam pembahasan seismotektonik kita mengharapkan informasi hiposenter berada tepat pada sistem patahan yang ada sesuai dengan kondisi tektonik yang ada serta penyimpangan yang lebih kecil. Relokasi gempabumi biasanya digunakan untuk melakukan identifikasi zona patahan berdasarkan distribusi gempa yang terjadi, sehingga dapat dipahami kondisi tektonik wilayah tersebut (Afnimar, 2009).

Salah satu metode relokasi yang sering digunakan adalah Metode Double Difference. Metode ini dugunakan karena bisa meminimalisir kesalahan model kecepatan tanpa menggunakan koreksi stasiun. Prinsip metode ini adalah jika jarak persebaran hiposenter antara dua gempabumi sangat kecil dibanding jarak antara stasiun dan gempabumi maka raypath waktu tempuh

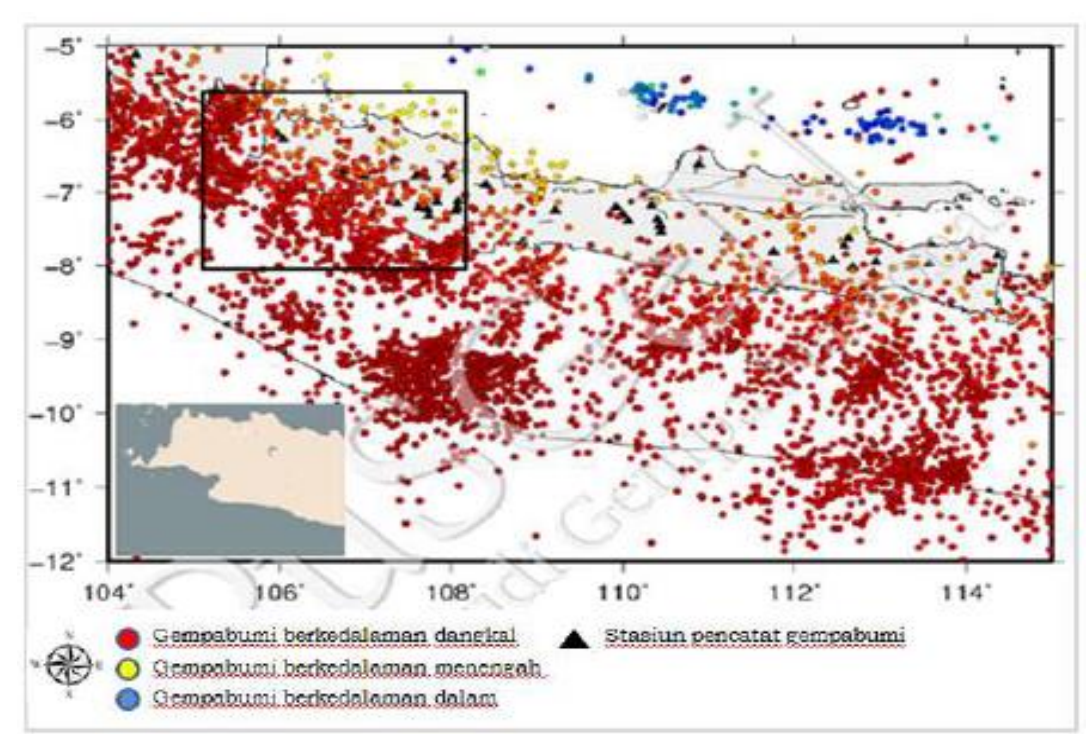

Gambar 1. Kegempaan Jawa bagian Barat (BMKG, 2019) 
dan waveform kedua gempa dapat dianggap mendekati sama. Dengan asumsi ini, maka selisih waktu tempuh antara kedua gempa yang terekam pada satu stasiun yang sama dapat dianggap hanya sebagai fungsi jarak antara kedua hiposenter (Waldhauser dan Ellsworth, 2000).

Penelitian ini menganalisis zona subduksi pada daerah Jawa bagian barat. Metode Double Difference (DD) digunakan untuk merelokasi hiposenter dan menggambarkan zona subduksi serta kedalaman gempabumi di daerah Jawa bagian Barat. Relokasi hiposenter diharapkan dapat mengklarifikasi sumber gempa yang terjadi sebagai parameter dasar seismotektonik untuk menunjang mitigasi gempabumi.

\section{METODOLOGI}

Data yang digunakan adalah data katalog gempabumi berupa arrival time gelombang $\mathrm{P}$, posisi hiposenter dan magnitudo gempa. Data yang digunakan dalam penelitian ini merupakan data gempabumi dengan magnitudo $\geq 3$ yang terjadi di Jawa bagian Barat dari Juli 2017 sampai Juli 2018 (Gambar 2). Data gempabumi yang diguanakan sebanyak 710 event yang terekam pada 9 stasiun (Tabel 1).

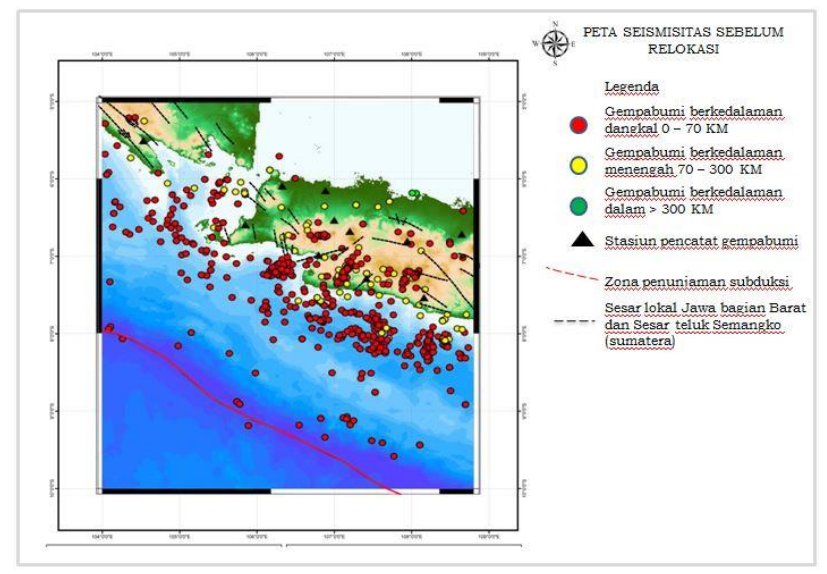

Gambar 2. Sebaran hiposenter Juli 2017-Juni 2018

Tabel 1. Lokasi Stasiun Pengamat Gempabumi

\begin{tabular}{|c|c|c|c|}
\hline N0 & Stasiun & Longitude & Latitude \\
\hline 1 & BBJI & -7.46 & 107.65 \\
\hline 2 & CBJI & -6.47 & 106.93 \\
\hline
\end{tabular}

\begin{tabular}{|l|l|l|l|}
\hline 3 & CGJI & -6.61 & 105.69 \\
\hline 4 & CNJI & -7.31 & 107.13 \\
\hline 5 & DBJI & -6.55 & 106.75 \\
\hline 6 & JCJI & -6.73 & 108.26 \\
\hline 7 & LEM & -6.83 & 107.62 \\
\hline 8 & SBJI & -6.11 & 106.13 \\
\hline 9 & TNG & -6.17 & 106.65 \\
\hline
\end{tabular}

Relokasi hiposenter dilakukan menggunakan metode Double Difference. Algoritma Double Difference dituangkan pada Gambar 3. Prinsip metode Double Difference adalah jika jarak persebaran hiposenter antara dua gempabumi sangat kecil dibandingkan dengan jarak antara stasiun gempabumi, maka raypath dan waveform kedua gempabumi dapat dianggap mendekati sama. Dengan asumsi ini, maka selisih waktu tempuh antara kedua gempabumi yang terekam pada satu stasiun yang sama dapat dianggap hanya sebagai fungsi jarak antara kedua hiposenter. Sehingga kesalahan model kecepatan bisa diminimalisasi tanpa menggunakan koreksi stasiun (Waldhauser dan Ellsworth, 2000).

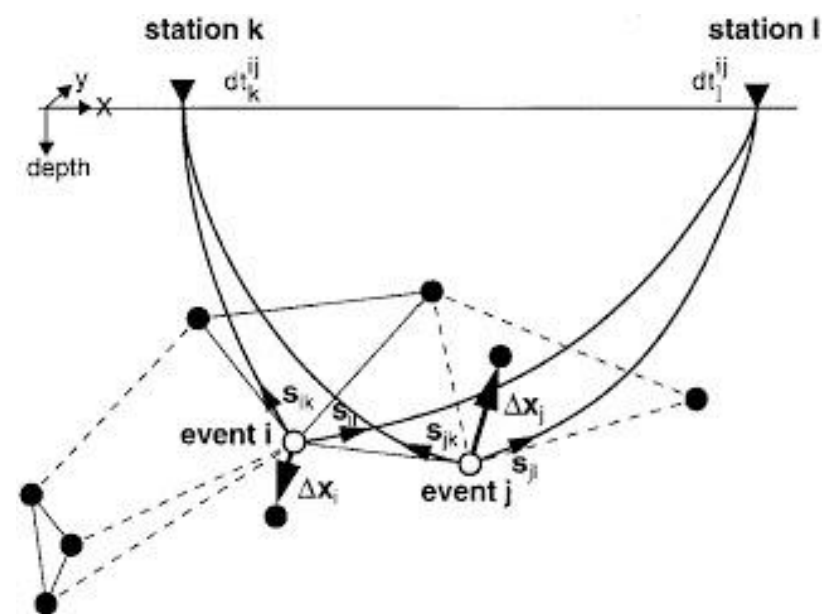

Gambar 3. algoritma metode Double Difference (waldhauser dan ellsworth, 2000)

Gambar 3 menunjukkan lokasi awal dari dua event $\mathrm{i}$ dan $\mathrm{j}$ yang direkam pada stasiun $\mathrm{k}$ dan $\mathrm{I}$. Lingkaran hitam merepresentasikan trial hypocenter yang dihubungkan ke hiposenter yang berada di sekitarnya menggunakan cross correlation (garis hitam) atau katalog (garis putus-putus). Notasi s 
adalah vector slowness, $\Delta x$ adalah vector perubahan event $\mathrm{i}$ dan $\mathrm{j}$, dan $\mathrm{dt}$ adalah selisih waktu tempuh antara event $\mathrm{i}$ dan $\mathrm{j}$ pada masing-masing stasiun $\mathrm{k}$ dan I.

Residual time antara pengamatan dan perhitungan $(\Delta d)$ merupakan perbedaan waktu tempuh observasi dan kalkulasi antara dua event gempabumi (Waldhauser dan Ellsworth, 2000) dan dapat dinyatakan dalam persamaan (1) :

$$
i k j=\left(t^{i k}-t^{i k}\right){ }_{o b s}-\left(t^{i k}-t^{i k}\right) c a l
$$

Persamaan tersebut adalah persamaan Double Difference. Merupakan waktu tempuh gelombang seismik ke stasiun $k$ akibat gempabumi $i$ dan merupakan waktu tempuh gelombang seismik ke stasiun $k$ akibat gempabumi j. Selanjutnya persamaan (1) dapat ditulis dalam bentuk persamaan 2:

$\Delta d=\frac{\Delta t^{i k}}{\partial m} \Delta m^{i}+\frac{\Delta t^{i k}}{\partial m} \Delta m^{j}$

Apabila dilakukan penguraian parameter perubahan model hiposenter $(\Delta \mathrm{m})$, persamaan 2 selanjutnya dapat dinyatakan menjadi :

$\Delta d=\frac{\Delta t^{i k}}{\partial x} \Delta x^{i}+\frac{\Delta t^{i k}}{\partial y} \Delta y^{i}+\frac{\Delta t^{i k}}{\partial z} \Delta z^{i}+\Delta t_{0}^{i}-$

$\frac{\Delta t^{j k}}{\partial x} \Delta x^{i}+\frac{\Delta t^{j k}}{\partial y} \Delta y^{i}+\frac{\Delta t^{j k}}{\partial z} \Delta z^{j}+\Delta t_{0}^{j}$

Persamaan 3 berlaku dalam satu klaster gempabumi. Apabila dinyatakan dalam bentuk matriks menjadi persamaan 4:

$\mathrm{W} \Delta \mathrm{d}=\mathrm{WG} \Delta \mathrm{m}$

Dimana $\Delta \mathrm{d}$ adalah matriks waktu residu berdimensi $\mathrm{m} \times 1 . \mathrm{m}$ dan $\mathrm{G}$ berturut-turut merupakan jumlah data observasi Double Difference dan matriks jacobi yang berdimensi $m \times 4 n$. $n$ dan $\Delta \mathrm{m}$ berturut-turut adalah $\mathrm{dxj}$ jumlah gempabumi dan matriks perubahan model yang berdimensi $4 n x$ 1 , sedangkan $w$ merupakan matriks diagonal yang menjadi pembobotan dalam persamaan perhitungan waktu tempuh gelombang. Proses iterasi terus dilakukan untuk memperbaiki parameter model hiposenter sehingga selisih waktu pengamatan dan waktu perhitungan akan mendekati nol. Persamaan 5 dan 6 berikut merupakan proses untuk memperbaiki parameter model dua hiposenter (Sunardi dkk., 2012).

$x_{0}^{i}=x_{0}^{i}+\Delta x^{i}+y_{1}^{i}=y_{0}^{i}++\Delta y^{i}+z_{1}^{i}=z_{0}^{i}+$ $+\Delta z^{i}+t_{01}^{i}=t_{01}^{i}+\Delta t_{0}^{i}$

$x_{0}^{j}=x_{0}^{j}+\Delta x^{j}+y_{1}^{j}=y_{0}^{j}++\Delta y^{j}+z_{1}^{j}=z_{0}^{j}+$ $+\Delta z^{j}+t_{01}^{j}=t_{01}^{j}+\Delta t_{0}^{j}$

Implementasi metode Double Different (DD) terangkum dalam program komputer yang dikenal dengan hypoDD. HypoDD memiliki 2 subprogram yaitu ph2dt dan hypoDD. Data gempabumi diatur membentuk pasangan gempabumi di dalam subprogram ph2dt. Pada penelitian ini digunakan dua variasi parameter jarak antara pasangan gempabumi (MAXSEP) yaitu $30 \mathrm{~km}$ dan $50 \mathrm{~km}$. Output dari ph2dt dipergunakan untuk merelokasi gempabumi menggunakan subprogram hypoDD. Diagram alir penelitian tertuang pada gambar 4 . 


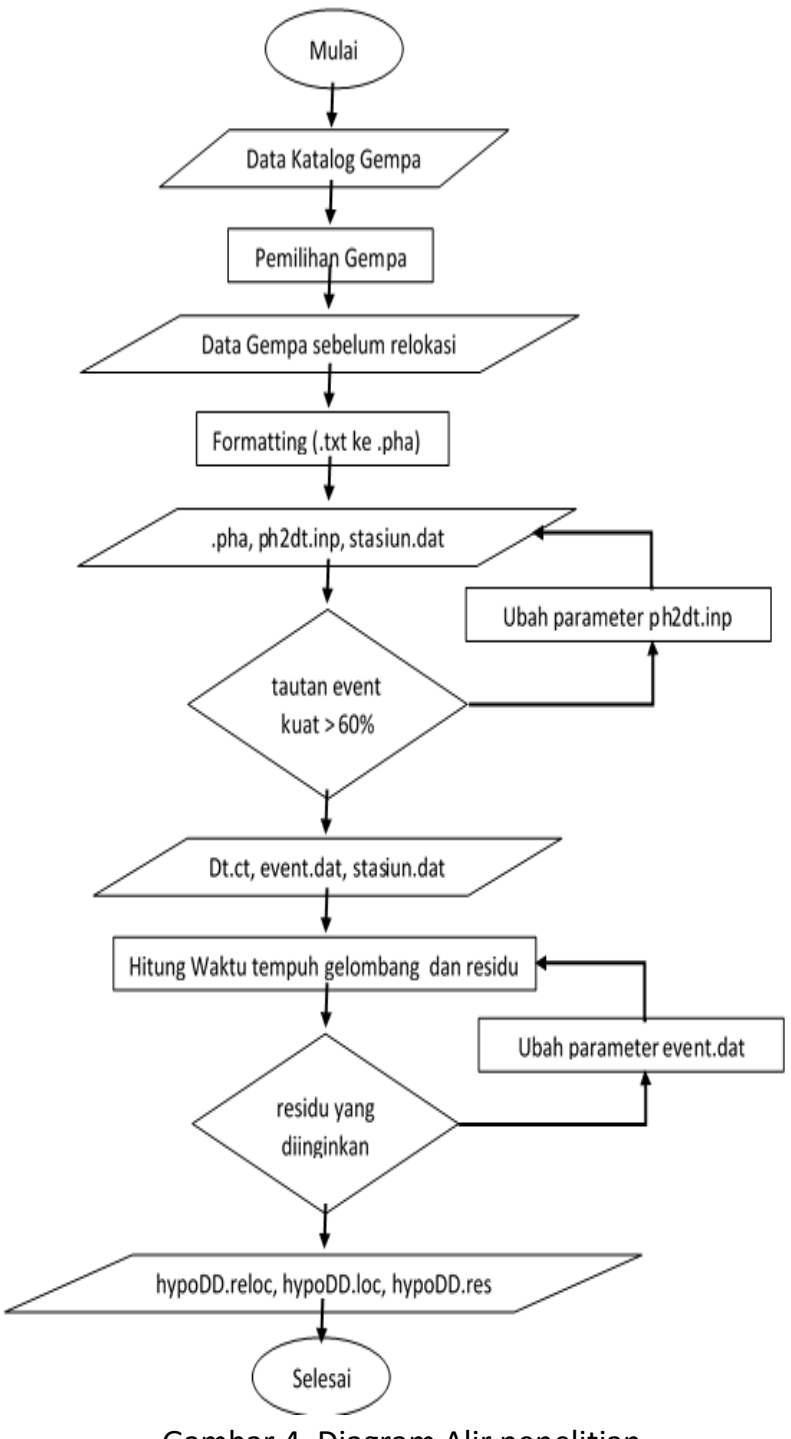

Gambar 4. Diagram Alir penelitian
Model kecepatan yang digunakan adalah model kecepatan global 1D IASP91 (Kennett dan Engdahl, 1991). Pada model kecepatan IASP91 diperhitungkan dua lapisan diskontinuitas pada lapisan kerak bumi yaitu di kedalaman 20 dan $35 \mathrm{~km}$. Model kecepatan ini memperhitungkan distribusi sumber event gelombang seismik buatan maupun gempabumi dan stasiun pencatat yang tidak seragam sehingga model kecepatan IASP91 sudah meliputi keheterogenitas batuan pada lapisanlapisan permukaan bumi (Bormann, 2013).

Penelitian ini digunakan variasi parameter jarak antara pasangan gempabumi terhadap pasangan gempabumi di sekitarnya (MAXSEP) yaitu 150 KM. Nilai CND atau condition number disesuaikan dengan jumlah cluster dan jumlah gempabumi. Nilai redaman CND (condition number) yang besar atau diluar 40-80 maka mengakibatkan gempabumi tidak mengalami perubahan posisi.

\section{HASIL DAN PEMBAHASAN}

Analisis dalam penelitian ini mencakupi analisa peta sebaran hiposenter sebelum dan setelah dilakukan relokasi. Gambar 2 merupakan peta sebaran hiposenter sebelum dilakukan relokasi. Pada Gambar 2 terlihat bahwa Jawa bagian Barat memiliki gempabumi dengan seismisitas yang tinggi. Hal tersebut karena aktivitas kegempaan di Jawa bagian Barat adanya patahan atau sesar aktif serta aktivitas

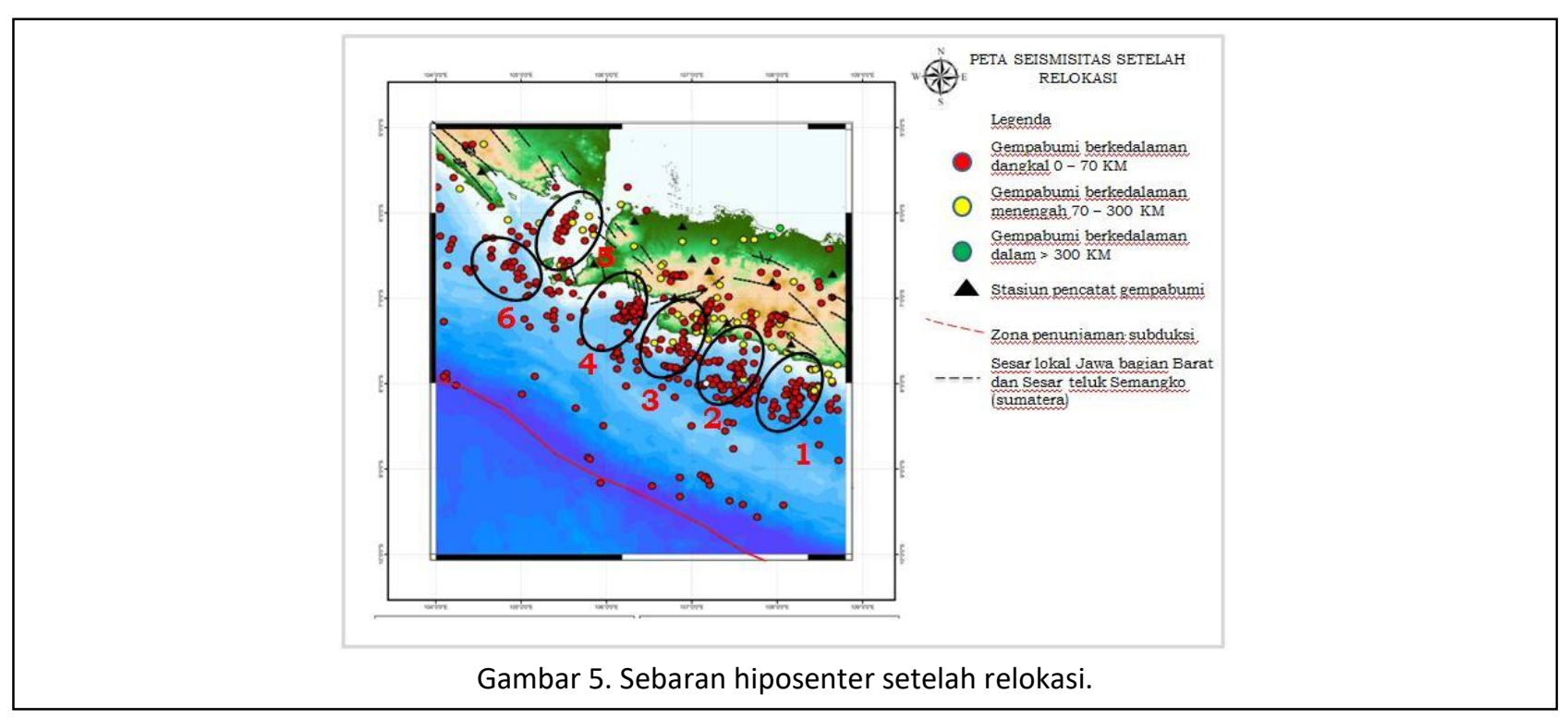


zona subduksi di Jawa bagian Barat. Gempabumi berkedalaman dangkal (pada titik merah) antara 0 $70 \mathrm{~km}$ tersebar di zona subduksi, sedangkan gempabumi kedalaman menengah (titik kuning) antara 70 - $300 \mathrm{~km}$ tersebar di zona subduksi dan sesar lokal, dan kedalaman dalam (titik hijau) $>300$ $\mathrm{km}$ tersebar di sesar lokal.

Sebaran hiposenter setelah dilakukan relokasi tertuang pada Gambar 5. Tidak terdapat perbedaan yang signifikan antara posisi hiposenter sebelum dan setelah relokasi. Jumlah gempabumi sebelum dilakukan relokasi sebanyak 710 gempabumi. Setelah dilakukan relokasi menjadi 510 gempabumi. Perbedaannya ada pada titik gempa yang lebih terkonsentrasi dan dapat di cluster berdasarkan sebaran lokasi hiposenter.

Gambar 5 juga menunjukkan hasil relokasi yang kemudian di cluster menjadi 6 daerah. Cluster ini dibuat berdasarkan lokasi distribusi sebaran hiposenter gempabumi yang berdekatan dan saling berkelompok. Selain itu masing-masing cluster memiliki karakteristik parameter gempa yang relatif sama. Cluster 1 terdiri dari gempa susulan dan gempabumi utama dengan skala Magnitudo 6.5. Cluster 2 merupakan gempabumi susulan yang terjadi dengan magnitudo yang lebih kecil dan tergolong gempa mikro. Cluster 3 merupakan gempabumi utama yang memiliki lokasi yang berdekatan.

Cluster 4 merupakan kejadian gempabumi utama sekaligus gempabumi susulan. Berdasarkan hasil relokasi hiposenter, gempabumi pada cluster ini merupakan gempabumi dengan aktivitas sesar local karena memiliki kedalaman yang relatifrelative dangkal dan berada pada daerah sesar lokal. Pada cluster ke 5 kemungkinan gempabumi berasosisi dengan kegempaan pada GAK (Gunung Anak Krakatau). Gempabumi pada cluster ini merupakan gempabumi mikro pada Gunung Anak Krakatau terekam oleh data BMKG. Jika di lihat dari kedalamannya, pada daerah Gunung Anak Kratakau ini kedalamannya dangkal. Sementara cluster 6 merupakan gempabumi dari aktivitas sesar lokal teluk semangko (dari Sesar Sumatera).

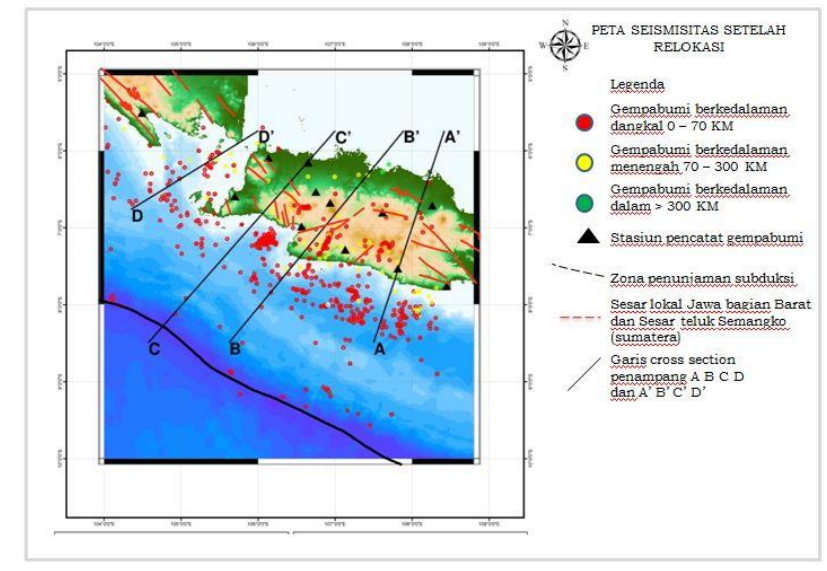

Gambar 6. Cross section

Penampang bawah permukaan dengan memotong garis disebut dengan cross section. Cross section dilakukan untuk melihat konsentrasi sebaran lokasi hiposenter dengan kedalaman hiposenter sehingga dapat diketahui bidang tektonik di bawah permukaan. Pada penelitian ini terfokus pada 4 garis cross section yaitu cross section $A-A^{\prime}, B-B^{\prime}$ dan $C-C^{\prime}$ serta $D-D^{\prime}$ (gambar 6). Hasil cross section pada gambar 6 ditunjukkan oleh gambar 7, gambar 8 , gambar 9, dan gambar 10. cross section diambil berdasarkan distribusi sebaran hiposenter gempabumi dan tatanan tektonik.

Berdasarkan hasil cross section pada penampang $A-A^{\prime}$, ditunjukkan penampang bawah permukaan A-A' (gambar 7) hasilnya menunjukkan hiposenter sebaran gempabumi berada di zona subduksi dangkal. Gempabumi berkedalaman dangkal hingga menengah ini menghasilkan bentuk rupa di zona subduksi. kedalaman dangkal 0-70 km berjumlah 150 event, kedalaman menengah 70-300 $\mathrm{km} 21$ event dan kedalaman dalam $>300 \mathrm{~km} 4$ event. Zona ini memiliki subduksi yang menunjam tajam dengan hiposenter gempa terkonsentrasi pada kedalaman dangkal dan tepat beradapada pertemuan 2 lempeng. 


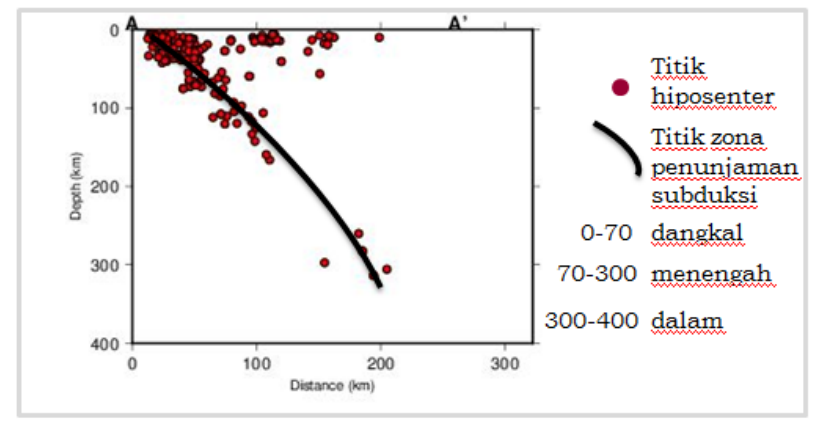

Gambar 7. Penampang vertikal hiposenter A dan A' setelah relokasi

Cross section B-B' menunjukkan sebaran hiposenter gempabumi pada zona subduksi dan aktivitas sesar lokal. Hiposenter gempabumi berada pada zona subduksi dangkal hingga dalam. Pola penunjamn yang terbentuk relatif tajam. Gempabumi dangkal terjadi akibat aktivitas zona subduksi dan patahan lokal. Patahan lokal pada zona ini adalah aktivitas deri Sesar Cimandiri, Sesar Lembang dan beribis (Gambar 8). Jumlah kedalaman dangkal 0-70 km berjumlah 218 event, kedalaman menengah 70-300 km 20 event dan kedalaman dalam $>300 \mathrm{~km} 4$ event.

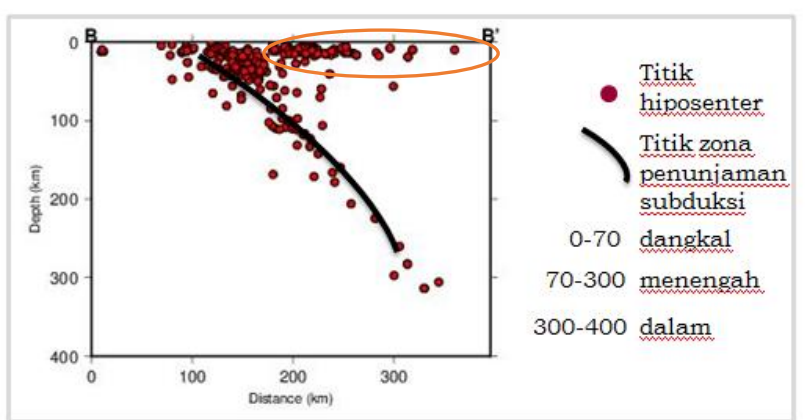

Gambar 8. Penampang vertikal hiposenter B dan B' setelah relokasi (lingkaran merah menunjukkan aktivitas sesar lokal)

Hasil cross section C-C' ditunjukkan pada gambar 9. Gambar tersebut memperlihatkan penampang bawah permukaan sebagai aktivitas zona subduksi dan aktivitas patahan pada daerah Jawa bagian Barat. Lokasi hiposenter pada zona subduksi terkonsentrasi pada zona hiposenter dangkal hingga dalam. Penunjaman yang terjadi relatif lebih landai daripada 2 zona cross section sebelumnya. Pada zona ini aktivitas kegempaan juga diduga disebabkan oleh aktivitas Sesar Citarik (lingkaran merah Gambar 9). aKtivitas kegempaan pada Sesar ini relatif dangkal $(<0-30 \mathrm{~km})$.

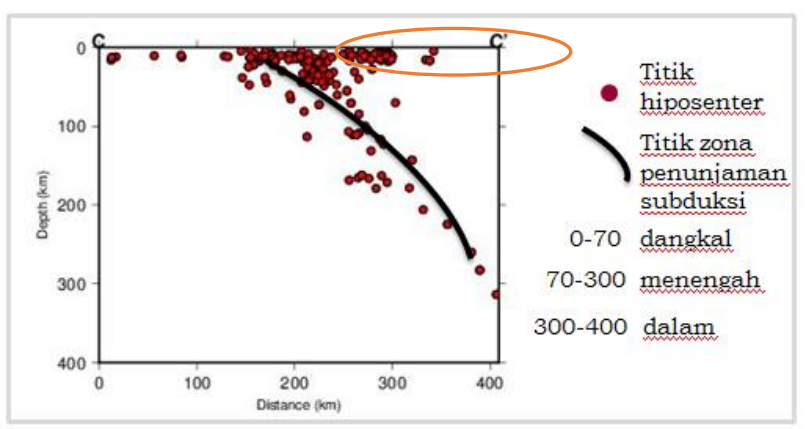

Gambar 9. Penampang vertikal hiposenter C dan C' setelah relokasi (lingkaran merah merupakan aktivitas sesar lokal)

Zona cross section pada penampang D-D' diduga ditenggarai oleh aktivitas vukanik G. Anak Karakatau di Selat Sunda. Aktivitas ini memiliki magnitudo gempabumi yang sangat kecil $<3 \mathrm{SR}$ atau tergolong gempa mikro dengan kedalam dangkal (Gambar 10, lingkaran hitam). Gempa dangkal lainnya diduga berasal dari aktivitas Sesar Semangko pada Segmen Teluk Semangko. Kondisi tektonik yang komplek di area Selat Sunda menyebabkan tingginya aktivitas gempa di zonaini (Ramdhan dan Nugraha, 2012).

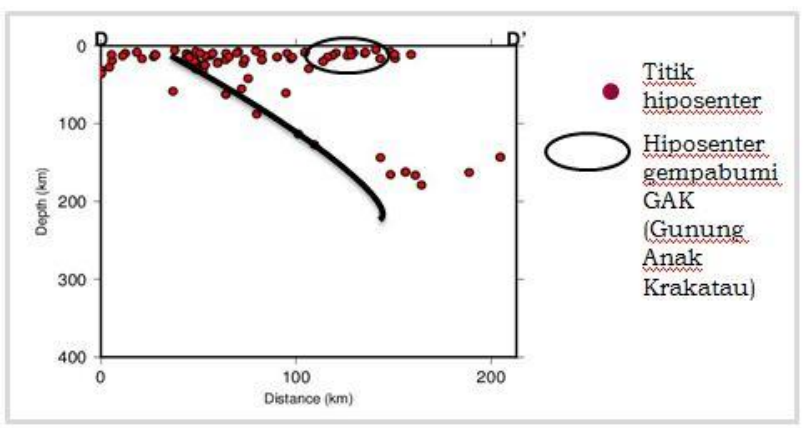

Gambar 10. Penampang vertikal hiposenter D dan D' setelah relokasi

\section{PENUTUP}

Penampang bawah permukaan memperlihatkan bahwa kegempaan di Jawa Barat sebagian besar diakibatkan oleh zona subduksi yang relatif landai. Gempabumi terjadi pada zona subduksi berada pada kedalaman 0-200 km (sebagian besar 0-70 km). Sesar-sesar lokal memberikan kontribusi yang tidak signifikan 
terhadap aktivitas kegempaan di jawa Barat. Akan tetapi, aktivitas kegempaan pada sesar lokal ini sangat dangkal, sehingga tetap berpotensi merusak ketika terjadi gempa dengan magnitude besar.

Untuk penelitian selanjutnya perlu dikaji lagi bagaimana mekanisme sumber di lokasi penelitian. Analisa diagram rose juga diperlukan untuk analisa arah pergerakan sesar ataupun arah sebaran gempabumi.

\section{DAFTAR PUSTAKA}

Afnimar (2009), Seismologi, Bandung : ITB.

Bormann, P. (2013), "Proposal for Unique Magnitude and Amplitude Nomenclature", New Manual of Seismological Observatory Practice 2 (NMSOP2), hal. $862 \mathrm{~kb}, \quad 26 \quad$ pages. http://doi.org/10.2312/GFZ.NMSOP-2_IS_3.2.

Hamilton, W.B., Indonesia, Departemen Pertambangan, United States, Agency for International Development dan Geological Survey (U.S.) (1979), Tectonics of the Indonesian Region, U.S. Govt. Print. Off., Washington.

Haryanto, I. (2006), "STRUKTUR GEOLOGI PALEOGEN DAN NEOGEN DI JAWA BARAT", Bulletin of Scientific Contribution: GEOLOGY, Vol.4, No.1. http://doi.org/10.24198/bsc geology.v4i1.8118.

Hilmi, F. dan Haryanto, I. (2008), "Pola Struktur Regional Jawa Barat", Bulletin of Scientific Contribution, Vol.6, No.1, hal. 57-66.

Katili, J.A. (1975), "Volcanism and plate tectonics in the Indonesian island arcs", Tectonophysics, Vol.26, hal. 165-188. http://doi.org/10.1016/00401951(75)90088-8.

Kennett, B.L.N. dan Engdahl, E.R. (1991), "Traveltimes for Global Earthquake Location and Phase Identification", Geophysical Journal International, Vol.105, No.2, hal. 429-465. http://doi.org/10.1111/j.1365246X.1991.tb06724.x.

Ramdhan, M. dan Nugraha, A.D. (2012), "Studi kegempaan area Selat Sunda dan sekitarnya berdasarkan hasil relokasi hiposenter menggunakan metode double difference", Jurnal JTM, Vol.19, No.4, hal. 184-189.

Sunardi, B., Rohadi, S., Masturyono, M., Widiyantoro, S., Sulastri, S., Susilanto, P., Hardy, T. dan Setyonegoro, W. (2012), "RELOKASI
HIPOSENTER GEMPABUMI WILAYAH JAWA MENGGUNAKAN TEKNIK DOUBLE DIFFERENCE", Jurnal Meteorologi dan Geofisika, Vol.13, No.3. http://doi.org/10.31172/jmg.v13i3.133.

Waldhauser, F. dan Ellsworth, W. (2000), "A DoubleDifference Earthquake Location Algorithm: Method and Application to the Northern Hayward Fault, California", Bulletin of the Seismological Society of America, Vol.90, hal. 1353-1368.

http://doi.org/10.1785/0120000006. 